\title{
MODYFIKACJE WZORÓW SOCJALIZACYJNYCH W RODZINIE W CZASACH NALOGOWYCH KONSUMENTÓW
}

Na skutek przemian cywilizacyjno-kulturowych w ostatnich kilkudziesięciu latach $^{1}$ pojawiły się w rodzinach polskich (i nie tylko, jakkolwiek nimi będziemy się tu głównie zajmować) swoiste zmiany sposobów kształtowania rzeczywistości życia rodzinnego. Mam tu na myśli modyfikacje relacji zachodzących wewnątrz i pomiędzy rzeczywistymi oraz konstruowanymi świadomościowo sferami aktywności (które za Peterem Bergerem i Thomasem Luckmannem² nazywać będę subświatami), a także zmiany połączonych z nimi konstelacji norm, wartości i wzorów zachowań. W interesującym mnie przypadku sa to głównie przestrzenie życia rodzinnego, chociaż nie tylko działania w obrębie świata życia rodzinnego będą poddane analizie ${ }^{3} \mathrm{w}$ niniejszym tekście.

Żyjemy w czasach płynnej rzeczywistości, a nieostrość granic jest jej odczuwalnym atrybutem. Zmiana ta wymusza na badaczach większą ostrożność w diagnozowaniu i opisie relacji pojawiających się pomiędzy subświatami, a mówiąc precyzyjniej - pomiędzy działaniami jednostek w kilku rzeczywistościach codzienności mniej lub bardziej równolegle. Jednoczesna obecność w dwóch światach (np. pracy i portalu społecznościowego) w zasadzie uniemożliwia większości tak działających osób osiaganie porównywalnie wartościowych efektów w obu sferach. Częstą konsekwencją w takich przypadkach jest tworzenie się przestrzeni granicznych, w których trudno jest jednoznacz-

${ }^{1}$ Mam na myśli okres około dwudziestu pięciu - trzydziestu lat.

${ }^{2}$ Społeczne tworzenie rzeczywistości. Traktat z socjologii wiedzy, tłum. J. Niżnik, PIW, Warszawa 1983.

${ }^{3}$ Rozważania zawarte $\mathrm{w}$ artykule wraz z elementami konstruowanej teorii empirycznej sa m.in. efektem rekonesansowego projektu badań zrealizowanego w latach 2013-2014 w Poznaniu i okolicznych osiedlach podmiejskich. W badaniach tych wzięło udział dobranych celowo (wykorzystano dobór metodą kuli śniegowej) 50 rodzin mieszkających z dziećmi w wieku 6-24 lat (wykluczono ewentualne mieszkanie z innymi członkami rodziny, np. teściami). Rodzice mieli wykształcenie wyższe i średnie oraz stałe zatrudnienie (eliminowano rodziny, w których już jeden z małżonków był zarejestrowanym bezrobotnym). Podstawową zastosowaną techniką był wywiad pogłębiony (przeprowadzany oddzielnie z każdym z małżonków oraz jednym dzieckiem) oraz obserwacja. Poza tym projektem w prezentowanym tekście korzystam z wyników i doświadczeń zgromadzonych podczas badań rodzin i młodzieży, które przeprowadziłem w latach 1991-1994, 1997-2000, 2003-2005 i 2006-2008 (zob. m.in. W. Wrzesień, Jednostka-rodzina-pokolenie. Studium relacji międzypokoleniowych $w$ rodzinie, Wyd. Naukowe UAM, Poznań 2003; idem, Europejscy Poszukiwacze. Impresje na temat wspótczesnego pokolenia polskiej młodzieży, PWN, Warszawa 2009). 
nie orzec, w jakim konkretnie subświecie dana jednostka się znajduje. Czy na przykład uczeń słuchający podczas lekcji matematyki muzyki z iPoda przebywa w subświecie matematyki czy muzyki? ${ }^{4}$

Rodzina, stanowiąc podstawową strukturę organizacji społecznego życia ludzi, w podobny sposób podlega zasygnalizowanemu powyżej procesowi. Tak więc przykładowo subświat czasu zabawy (rodziców lub jednego z nich z małymi dziećmi) w naturalny sposób towarzyszy subświatowi wychowania, przeważnie wspomagając go. Natomiast subświaty grup towarzyskich czy przyjacielskich, oddzielne dla rodziców i ich dorastających dzieci ${ }^{5}$, mogąjuż znaczaco zaburzać relacje w przestrzeniach wewnątrzrodzinnych oraz rodzić konflikty wymagajace podejmowania wysiłków negocjacyjnych i kontrolnych. Granice pomiędzy działaniami typowo wewnątrzrodzinnymi (subświat obowiązów opiekuńczych, zaspokajanych potrzeb bliskości emocjonalnej, bezpieczeństwa, akceptacji, ale również subświat kulinarny, napraw i remontów itp.) a działaniami, jeżeli nie pozarodzinnymi, to przynajmniej bardziej od rodziny oddalonymi (subświat rzeczywistości Internetu, zawodowy, zaangażowania w sferze publicznej itd.) stały się dzisiaj znacząco mniej wyraźne. Dodatkowo wraz ze wzrostem tempa życia i koniecznościa elastycznej rodzinno-pozarodzinnej wielozadaniowości (odwożenie dzieci w drodze do pracy, natychmiastowe odpowiadania w trakcie realizacji innych zadań, np. zawodowych, na SMS-y, e-maile czy telefony od dzieci, stałe nadzorowanie ich aktywności „na odległość" itp.) świat życia rodzinnego zarówno silniej zaznacza swoją obecność poza własna sfera prywatną (wyjazdy wakacyjne dla rodzin, atrakcje czasu wolnego dla rodzin, nawet promocje produktów niezwiązanych z rodzina - dla rodzin $^{6}$, polityka państwa dla rodzin, zatrudnienie przyjazne rodzinom itp.), jak i coraz wyraźniej dopuszcza do własnej przestrzeni rzeczywistości zewnętrzne. Przede wszystkim zasygnalizowane powyżej zmiany zawdzięczamy rozwojowi nowoczesnych technologii komunikacyjnych i równoległemu życiu w przestrzeni realnej i wirtualnej, chociaż proces ten, zapoczątkowany jeszcze w czasach prasy, a później radia, znacząco zdynamizowany został przez telewizję, która nadal odgrywa w nim niebagatelną rolę.

Otaczające nas dzisiaj płynne przejścia pomiędzy dotychczas wyraźnie zdefiniowanymi przestrzeniami - subświatami konstruowanej w interakcjach rzeczywistości - miały i maja głębsze przyczyny, wynikające z przemian politycznych i ekonomicznych. Nie sposób w realiach polskich ignorować przebiegu oraz konsekwencji transformacji ustrojowej, stopniowego budowania zasad gospodarki rynkowej oraz coraz silniej zaznaczającej się dominacji kultury konsumpcyjnego kapitalizmu. Przemiany rzeczywistości życia rodzinnego

${ }^{4}$ Nawiązuję tu do koncepcji liminalności przydatnej w analizach innowacji pojawiających się we współczesnym życiu społecznym (zob. m.in. B. Martin, A Sociology of Contemporary Cultural Change, Blackwell, Oxford 1985; V. Turner, Proces rytualny. Struktura i antystruktura, tłum. E. Dżurak, PIW, Warszawa 2010).

${ }^{5} \mathrm{~W}$ niniejszym tekście z powodów czysto redakcyjnych terminem „dziecko/dzieci” obejmować będę również osoby w wieku młodzieżowym, czyli 11-30 lat (zob. przyp. 16).

${ }^{6}$ Znane mi są przypadki firm farmaceutycznych i medycznych, ale inne branże również często organizują (darmowe) atrakcje dla całych rodzin klientów w celach marketingowych, starając się w ten pozornie niebezpośredni sposób wzmacniać przywiązanie do własnych produktów. 
w Polsce, mimo swoich regionalnych cech, wpisały się również w ogólny ciag tendencji typowych dla kręgu kulturowego Zachodu? ${ }^{7}$ Mówiąc krótko, mimo że zasadniczo zakres realizowanych przez rodziny zadań nie uległ w ostatnich latach istotnym przeobrażeniom (regulacja relacji seksualnych i prokreacji, socjalizacja i wychowanie, tworzenie emocjonalnego, materialnego i ekonomicznego zaplecza egzystencji ludzi itp.), to jednak dzisiejsze rodziny nie sa takie same, jakimi jeszcze były 40 lat temu.

Oczywiście można powiedzieć, że jest to naturalny proces, który towarzyszy ludzkiej cywilizacji od początków jej istnienia. Taka jest przecież zwykła kolej rzeczy. Oprócz tego należy również pamiętać, że istnieje spora grupa osób tworzących swoje światy życia rodzinnego w sposób tradycyjny ${ }^{8}-$ kultywuje dawne wzory, jedynie nieznacznie poddając je modyfikacjom dostosowującym do specyfiki swoich czasów i miejsc. Niektórzy mogą zatem stwierdzić, że z żadną rewolucją w rodzinie nie mamy do czynienia. Owszem prawda, jednak dynamika przemian ostatnich kilkudziesięciu lat, w moim przekonaniu, wymaga, abyśmy na chwilę zatrzymali się i spróbowali dokonać chłodnej oceny nowych cech w rodzinnych przestrzeniach.

Mając świadomość, że proces potencjalnych zmian może przebiegać na kilku płaszczyznach i mieć wielowątkowy charakter ${ }^{9}$, w niniejszym opracowaniu zajmiemy się jego socjalizacyjnym fragmentem. W moim przekonaniu socjalizacja, jako proces trwający przez całe nasze życie, zajmuje tutaj centralne miejsce i od realizowanych w jej ramach wzorów należy rozpocząć analizę przemian świata życia rodzinnego.

Socjalizacja doczekała się wypracowania w naukach społecznych wielu stanowisk teoretycznych, które w konsekwencji doprowadziły do współwystępowania licznych, niekiedy konkurujących ze soba, konwencji definicyjnych. Nieco inaczej socjalizację postrzegają pedagodzy, psycholodzy czy socjolodzy. Nie zagłębiajac się w zasygnalizowany tu problem, na potrzeby niniejszego opracowania przyjmuję, że socjalizacja to proces uspołecznienia, „dzięki któremu jednostka wdraża się do sposobu życia swojej grupy i szerszego społeczeństwa przez uczenie się reguł i idei zawartych w kulturze"10, tworzy i rozwija osobowość oraz staje się „podmiotem zdolnym do społecznego działania”11. To proces składajacy się z dwóch etapów i (zarazem) dwóch płaszczyzn. Pierwszym, stanowiącym podstawę, bazę wszystkich kolejnych, jest wprowadzanie

\footnotetext{
${ }^{7}$ Mając pełną świadomość kulturowych różnic charakteryzujących specyfiki życia rodzinnego w różnych krajach Europy Zachodniej czy Ameryki Północnej, w niniejszym tekście będę nawiązywał do podobieństw, które występują w tych krajach i uaktywniają się również w przestrzeniach życia rodzinnego w Polsce.

${ }^{8}$ I wcale nie mam tu na myśli ortodoksyjnych wyznawców konserwatywnych odłamów religii czy mieszkańców małych osad wiejskich, sytuowanych daleko od ośrodków miejskich i przemysłowych.

${ }_{9}$ Analizy przemian świata życia rodzinnego (stanowiącego i tak mniej lub bardziej spójną całość) mogą przykładowo koncentrować się na sferze ekonomicznej, osiagania celów związanych $\mathrm{z}$ kariera zawodowa, wkraczaniu w sferę publiczną czy modyfikacji systemu wewnątrzrodzinnej władzy.

${ }_{10}$ P. Sztompka, Socjologia. Analiza społeczeństwa, Znak, Kraków 2003, s. 416.

${ }^{11}$ K.-J. Tillmann, Teorie socjalizacji. Społeczność, instytucja, upodmiotowienie, PWN, Warszawa 2013, s. 6.
} 
nowych jednostek do społeczeństwa - określane mianem socjalizacji pierwotnej. Jej realizacja w przeważającej większości spoczywa na rodzinie pochodzenia. Drugim etapem, a właściwie poprawnie mówiąc, zbiorem przebiegających po socjalizacji pierwotnej dalszych, następnych socjalizacji, układających się $\mathrm{w}$ wielowymiarowe przestrzenie naszego życia - jest socjalizacja wtórna ${ }^{12}$.

$\mathrm{W}$ rodzinie $\mathrm{w}$ efekcie przebiegu procesu socjalizacji pierwotnej dochodzi do „internalizacji społeczeństwa jako takiego” i subiektywnego ustanowienia spójnej i trwałej tożsamości jednostki ${ }^{13}$. Tutaj również przebiegają nieustannie konfrontacje różnic normatywnych (np. innych hierarchii uznawanych norm i wartości) pomiędzy socjalizacją pierwotną a socjalizacją wtórną. Rodzina w trakcie wszystkich etapów swojego cyklu życia jest przestrzenia permanentnej socjalizacji, a jej efekty warunkują zarówno poziom jakości życia rodzinnego, jak i nasze aktywności w przestrzeniach pozarodzinnych.

W świetle interesujących nas modyfikacji świata życia rodzinnego ważny jest jeszcze jeden element procesu socjalizacji, rzadko w socjologii rodziny diagnozowany (dostrzegany). Każdy już na etapie procesu socjalizacji pierwotnej w rodzinie, oprócz internalizacji społecznych oczekiwań, norm, wartości i wzorów (w pierwszym etapie komponujących konieczny zbiór cech uogólnionego innego) oraz umiejętności współtworzenia przestrzeni wspólnych (stanowiących podstawy wspólnych działań), nabywa również zdolności do tworzenia swoich prywatnych przestrzeni.

W późniejszym życiu dzięki dalszym różnicującym wpływom przebiegu procesu socjalizacji wtórnej doskonalimy nasze umiejętności, a konstruowane przez nas prywatne przestrzenie - zarówno poza rodzina, jak i w jej ramach pomagają nam w realizacji scenariuszy różnych ról społecznych, w tym w rodzinie. Z jednej strony niekiedy sprzyjają koniecznemu nabraniu większego dystansu, którego skrajnym przypadkiem może być odizolowywanie się od niesatysfakcjonujących nas działań, z drugiej natomiast - wspomagają w nawiązywaniu efektywnych form kooperacji przy jednoczesnym wyraźnym wytyczaniu granic i wskazywaniu istoty własnych interesów we wspólnym dążeniu do wypracowania najkorzystniejszych dla rodziny form konsensusu.

Zazwyczaj w pracach poświęconych życiu rodzinnemu rodzina traktowana była jako względnie spójna całość (grupa społeczna, instytucja społeczna,

\footnotetext{
${ }^{12}$ Należy w tym miejscu zaznaczyć, że inaczej, niż analizowali to przywoływani poniżej Peter Berger i Thomas Luckmann, przyjmuję, iż w ramach socjalizacji wtórnej może pojawiać się, podobnie jak w socjalizacji pierwotnej, silna identyfikacja emocjonalna $\mathrm{z}$ osobami, z którymi wchodzimy w interakcje (np. w grupie rówieśniczej). Szerzej problem ten omawiam gdzie indziej (W. Wrzesień, Jednostka - rodzina - pokolenie..., passim).

${ }^{13}$ Przede wszystkim chodzi tutaj o ukształtowanie się w świadomości człowieka konstruktu nazwanego przez George'a Herberta Meada „uogólnionym innym” (por. idem, Umyst, osobowość $i$ społeczeństwo, PWN, Warszawa 1975). Z jednej strony jest to szeroko pojmowany zbiór oczekiwań związanych z pełnieniem różnych ról społecznych w danym miejscu i czasie, z drugiej natomiast - to uświadomienie sobie istnienia rozległej (szerszej niż rodzina pochodzenia, krag znajomych, sąsiadów czy przyjaciół), całościowej perspektywy społecznej rzeczywistości. Jak piszą Berger i Luckmann, jest to „abstrahowanie od ról i postaw konkretnych znaczacych innych” (np. rodziców) i „dostrzeżenie ról i postaw w ogóle” (P. L. Berger, T. Luckmann, op. cit., s. 207 -208), oznaczające koniec identyfikacji wyłącznie z naszymi najbliższymi, a początek identyfikacji z całym społeczeństwem (ibidem, s. 208).
} 
wspólnota). Niezależnie od przyjmowanych założeń natury metodologicznej wspólną cechą przeważającej części socjologicznych analiz było traktowanie życia rodzinnego w kategoriach jednej przestrzeni zasiedlanej przez tworzące rodzinę jednostki ${ }^{14}$. W jej ramach oczywiście badano różnorodne konstelacje i układy wzajemnych relacji, jednak wspólnym mianownikiem i tak pozostawała rodzina jako całość.

Teza o jednej rodzinnej przestrzeni - niekiedy wyraźnie akcentowana, a niekiedy przyjmowana milcząco - wymaga $\mathrm{w}$ świetle interesujących nas zjawisk rewizji, a w zasadzie odrzucenia. Wspólne mieszkanie (prowadzenie wspólnego gospodarstwa domowego) wcale nie musi i z reguły nie skutkuje tworzeniem jednej przestrzeni świata życia rodzinnego - jej po prostu nie ma. Są tylko przestrzenie wspólne, w niektórych sytuacjach dzielone przez wszystkich (np. rytualnie spożywane posiłki, uroczystości, święta itp.), a w przeważającej większości rodzinnego czasu tylko przez niektórych członków rodzin. W zależności od tego, kogo włączamy albo kto jest przez samych członków rodzin włączany do rodziny, możemy obserwować mniej lub bardziej złożone układy podgrup. Możemy wymienić tu pary, takie jak małżonkowie, rodzeństwo, rodzic-dziecko czy dziadek-wnuk lub większe podgrupy w liczniejszych rodzinach. Powyższą perspektywę uzyskujemy przy zastosowaniu optyki materialnej, w zasadzie skupiając się głównie na ludziach oraz otaczających ich i wykorzystywanych przez nich przedmiotach. Inaczej sprawa ma się wówczas, gdy w zakresie naszych zainteresowań usytuujemy przestrzenie symboliczne, tworzace się wokół realizowanych działań i sprzężonych z nimi norm oraz wartości. Tutaj możemy dostrzec kolejne wewnątrzrodzinne linie podziałów, które w połączeniu z perspektywą materialną pozwalają nam na wyselekcjonowanie występujących w rodzinie subświatów.

I tak możemy mówić o subświecie relacji seksualnych, subświecie prokreacyjnym, wychowania, czasu wolnego, zabawy, rodzinnych świąt, wakacji, ekonomicznym, rodzinnej władzy, sytuacji kryzysowych, subświecie gospodarstwa domowego i wielu innych, nierzadko stanowiących indywidualne specyfiki funkcjonowania poszczególnych rodzin - o wiele bardziej elastyczne niż statycznie ujmowane (w kategoriach struktur) przestrzenie świata życia rodzinnego.

W wersji modelowej małżonkowie-rodzice tworzą jedną wspólną przestrzeń. W praktyce życia codziennego jest to raczej konglomerat wielu przestrzeni, w których nie zawsze oboje małżonkowie funkcjonują równie silnie zaangażowani i na tych samych prawach ${ }^{15}$. Gdy dodamy dzieci, w zasadzie

${ }^{14}$ Współcześnie, jak przekonywał Tomasz Szlendak, przeważać zaczynają definicje elastyczne, traktujące rodzinę jako proces, a nie strukturę, wskazujące na subiektywność ocen, kogo zaliczamy do rodziny oraz podkreślające konieczność wystapienia w jej ramach przynajmniej jednej z diad: rodzic-dziecko, partner-partner (zob. T. Szlendak, Socjologia rodziny. Ewolucja, historia, zróżnicowanie, PWN, Warszawa 2010). Ważne jest też w tym kontekście stwierdzenie Anny Gizy-Poleszczuk, zawarte w rozważaniach nad modelem pojęciowym rodziny, że „rodzina jest [...] radykalną abstrakcja”" (A. Giza-Poleszczuk, Rodzina a system społeczny. Reprodukcja $i$ kooperacja w perspektywie interdyscyplinarnej, WUW, Warszawa 2005, s. 43), co w moim odczuciu szczególnie trafnie oddaje naturę konstruowanych w ostatnich latach rzeczywistości życia rodzinnego.

15 Jako przykład niech posłużą nam tu chociażby stereotypowo postrzegane różnice pomiędzy światem kuchni (kobiecym) i garażu (męskim) czy zróżnicowania kompetencji, wynikające z wy- 
wspólna przestrzeń, zarówno w sensie symbolicznym (bardziej) i materialnym (mniej), tworzą one z rodzicami przeważnie aż do momentu ukonstytuowania uogólnionego innego i rozpoczęcia socjalizacji wtórnej z rówieśnikami (przede wszystkim w szkole). Wraz z wiekiem, a szczególnie po wkroczeniu w wiek młodzieżowy ${ }^{16}$, dzieci zaczynają budować swój świat podobnie jak ich rodzice. Teraz komponuja już złożone zbiory różnorodnych subświatów, w których nierzadko wypracowywany jest silny aksjologiczno-normatywny potencjał alternatywny wobec wcześniejszej, spójnej (jednej) rodzinnej przestrzeni. W konsekwencji wzajemne relacje pomiędzy siłami występującymi w ramach przestrzeni rodziców i dorastających dzieci tworzą nowe przestrzenie wspólne, modyfikują normy, wartości i wzory zachowań, między innymi współdefiniując subiektywne odczuwanie jakości życia rodzinnego. Obiektywnie natomiast odpowiedzialne są za spójność rodziny i - niewprowadzające zaburzeń w przestrzeniach subświatów zewnętrznych - sposoby wkraczania i funkcjonowania w nich.

Pojawiające się odstępstwa od norm, zaburzające dotychczas istniejące i realizowane scenariusze działań w subświatach zewnętrznych, często stanowią konsekwencje zmian procesu socjalizacji w rodzinie, a w zasadzie sa efektami jego nieskuteczności lub nieadekwatności. Jeżeli nikt, albo przynajmniej wielu (na zasadzie zgniłego jabłka, „bo jak on może, to ja też), nie zna lub ignoruje do tej pory społecznie aprobowane normy i wzory zachowań lub sam je sobie wybiera/tworzy (gdyż tak mu najwygodniej), będąc produktem współczesnej ideologii indywidualizacji, to społeczeństwu zaczyna grozić stan anomii i poważne kłopoty. Płynna rzeczywistość współczesności w wielu swoich niejasno zdefiniowanych granicach, przejściach, przestrzeniach wspólnych sprzyja tworzeniu, nierzadko marketingowo promowanych i społecznie akceptowanych, stanów „normalnej” anomii - pochodnych rozwoju kapitalizmu. Niegdyś „poważny” - dorosły kapitalizm na takie rozchwianie by nie pozwalał. Od kapitalizmu inwestycyjnego, z jego etyką protestancka, etosem ciężkiej pracy, długofalowym planowaniem i systematycznym oszczędzaniem, przez kapitalizm liberalny i menadżerski, znacznie wzmacniające autonomię i pozycję jednostki, jej wybory i prawa w świecie życia codziennego oraz jego subświatach, stany rozregulowania czy niejasności reguł szybko korygowane były przez czujność systemu kontroli społecznej wspomagającego procesy socjalizacji wtórnej.

Dzisiejszy zinfantylizowany kapitalizm konsumpcyjny bardziej podsyca, niż stara się gasić nastroje niejednoznaczności i elastyczności większości norm i wzorów, gdyż dzięki temu może maksymalizować sprzedaż-konsumpcję, na której się opiera, i promuje nowy typ bohatera - nałogowego konsumenta ${ }^{17}$.

kształcenia lub wykonywanego zawodu (np. matka lekarz dba o zdrowie, a ojciec księgowy pilnuje podatków).

${ }^{16} \mathrm{~W}$ mojej perspektywie badawczej przyjmuję, że symbolicznie wiek młodzieżowy rozpoczyna 11 rok życia, kończy go przekroczenie 30 lat. Szerzej problem ram autonomicznej kategorii młodzieży i subtelności jej definiowania w socjologii omawiam gdzie indziej (zob. W. Wrzesień, Krótka historia młodzieżowej subkulturowości, PWN, Warszawa 2013).

${ }_{17}$ B. R. Barber, Skonsumowani. Jak rynek psuje dzieci, infantylizuje dorostych i potyka obywateli, tłum. H. Jankowska, Muza, Warszawa 2008, s. 86. 
Z tego też między innymi powodu procesy socjalizacji (przede wszystkim wtórnej, ale socjalizacji pierwotnej również) zaczynają współcześnie charakteryzować się cechami nowej (obecnie pożądanej) niepomyślnej socjalizacji ${ }^{18}$. W ramach socjalizacji pierwotnej nieudolnie realizowane modele życia rodzinnego ${ }^{19}$ wprowadzaja zawirowania socjalizacyjno-wychowawcze skutecznie wykorzystywane przez dzieci, które zamiast uczyć się przestrzegania reguł, uczą się ich obchodzenia - przeważnie manipulacyjnego balansowania pomiędzy różnymi wersjami tego samego lub różnych światów - gry własna, jeszcze kształtującą się tożsamościa. Ta zdolność z kolei staje się kluczową dla współczesnych socjalizacji wtórnych, które - aby móc podsycać cechy nałogowego konsumenta - wymagają możliwości płynnego przemieszczania się pomiędzy różnymi tożsamościami.

Definiowany przez Bergera i Luckmanna typ społeczny indywidualisty, posiadający przynajmniej zadatki na migranta między różnymi dostępnymi światami, swoją osobowość budował świadomie z „materiału” zapewnianego przez wiele różnych tożsamości ${ }^{20}$. Współczesny indywidualistyczny nałogowy konsument już świadomie swojej osobowości nie konstruuje, chociaż tak mu się wydaje i tak mu się wmawia. Jego świadomość znajdowania się pod wpływem oddziaływań ukierunkowanych na konstruowanie jego własnej osobowości i de facto bycia plastycznie modyfikowanym oraz kierowanym jest skutecznie przytłumiana przez konsekwentne przekonywanie go, kim jest, a on bardzo chce w to wierzyć. Podobnie jak w przypadku typu indywidualisty Bergera i Luckmanna jego stałą zinternalizowaną cechą autopercepcji sa możliwości alternacji, które również postrzega on w kategoriach możliwego życiowego wyboru, jednak nie zauważa, że jest zdalnie sterowany, a jego autonomiczne wybory są pozorne, przeważnie zaplanowane w kampaniach marketingowych.

W świecie kultury konsumpcyjnego kapitalizmu „»dobre społeczeństwo«, czyli środowisko gościnne dla człowieczeństwa swych członków i to człowieczeństwo gwarantujące” zastępuje „społeczeństwo "łowców“"21 - konsumentów, którym wmawia się wręcz nieograniczone zdolności indywidualnego komponowania własnych światów, podsycając przede wszystkim potrzebę (konieczność) stałego poszukiwania zmian i podążania za nimi. Sensem życia

\footnotetext{
18 Por. P. Berger, T. Luckmann, op. cit., s. 249-260.

${ }_{19}$ Paradoksalnie sytuacja ta dotyczy przede wszystkim modelu partnerskiego i mieszanego. W socjologii możemy spotkać kilka typologii modeli rodziny czy życia rodzinnego. Na potrzeby naszych rozważań wykorzystuję stosowany w badaniach CBOS-u podział na: a) model partnerski (w którym małżonkowie/partnerzy w równym stopniu poświęcają się pracy i obowiązkom domowym); b) model mieszany (oboje małżonkowie/partnerzy pracują ale mężczyzna poświęca więcej czasu na pracę zawodowa, a kobieta łączy pracę zawodową z prowadzeniem domu i wychowaniem dzieci); c) model tradycyjny (w którym mąż/partner zajmuje się utrzymaniem rodziny, a żona/ partnerka domem); oraz d) model odwrócony (gdy żona/partnerka pracuje i utrzymuje rodzinę, a mąż/partner przejmuje obowiązki domowe) (CBOS, Potrzeby prokreacyjne oraz preferowany $i$ realizowany model rodziny. Komunikat z badań, BS/61/2012, Warszawa 2012, s. 5). Model partnerski i model mieszany, będąc najczęściej deklarowanymi przez Polaków zarówno jako pożądane, jak i realizowane (ibidem) często narażone są na zewnętrzne wpływy modyfikujące wewnętrzne relacje socjalizacyjne, kontrolne i wewnątrzrodzinnej władzy oraz takim wpływom ulegają.

20 Zob. P. Berger, T. Luckmann, op. cit., s. 257-260.

21 Z. Bauman, Kultura w płynnej nowoczesności, Agora, Warszawa 2011, s. 43.
} 
staje się nieustanna pogoń/polowanie, traktowane w kategoriach dobrej zabawy, połaczone z nieprzywiązywaniem się do zdobyczy, szybkim nudzeniem się nimi i wyrzucaniem z własnego życia.

Konsumpcyjny kapitalizm wykorzystuje nasza naturę drapieżnika-myśliwego oraz specyfikę funkcjonowania naszego mózgu, której zawdzięczamy skłonność do uzależnień. Specjaliści od marketingu już dawno tę cechę zauważyli i z powodzeniem uwzględniają ją w swoich działaniach. Natomiast w ostatnich latach w wyniku rozwoju nauk medycznych, neurobiologii, kognitywistyki w świecie marketingu wprowadzone zostały nowe możliwości diagnozowania i w konsekwencji konstruowania potencjalnie bardziej skutecznych form wpływu w realizowanych działaniach.

Zmianę tę zainicjowały odkrycia dotyczące mechanizmu działania dopaminy. Jak dowiedli w badaniach Kent C. Berridge i Terry E. Robinson ${ }^{22}$, dopamina nie jest neuroprzekaźnikiem jedynie odpowiedzialnym za kontrolę systemu przyjemności w mózgu, motywując nas dzięki odczuwaniu zadowolenia i przyjemności do poszukiwań pożywienia, seksu czy narkotyków ${ }^{23}$. Wskazane badania dowiodły, że dopamina jest nie tyle odpowiedzialna za doświadczanie przyjemności, ile za same zachowania poszukiwawcze. Dopamina powoduje, że chcemy, pragniemy, pożądamy, wyszukujemy i szukamy. Podnosi poziom pobudzenia i intensywność działań zorientowanych na realizację celu. Tak skonstruowany dopaminowy system poszukiwawczy utrzymuje nasza motywację do wszelkiej aktywności, nauki i przetrwania w otaczającym świecie. Poza tym stymuluje oprócz potrzeb fizycznych również poszukiwania abstrakcyjnych idei. Generuje ciekawość i dostarcza energii do poszukiwań informacji.

Wspomniane badania dowodza, że oprócz dopaminy w interesującym nas procesie ważną rolę odgrywa układ opioidowy mózgu, odpowiedzialny za odczuwanie przyjemności. Dwa wspomniane systemy - dopamina i układ opioidowy uzupełniaja się - dopamina stymuluje działania, a układ opioidowy nagradza odczuwaniem satysfakcji (przyjemności) i wtedy następuje (przeważnie krótka) przerwa w poszukiwaniach. Ze względu na to, że dopamina jest silniejsza niż układ opioidowy, pragnienie poszukiwań jest silniejsze niż odczuwanie stanu satysfakcji ${ }^{24}$. W efekcie tworzą się pętle dopaminowe - zaczynasz szukać, znajdujesz, zostajesz nagrodzony, co stymuluje do dalszych, jeszcze bardziej intensywnych poszukiwań.

Szczególnie wyraźnie cecha ta współcześnie zaznacza swoją obecność w wykorzystywaniu nowoczesnych technologii komunikacyjnych. Coraz trudniej jest wyrwać się z wirtualnej rzeczywistości, pisania e-maili, SMS-ów, rozmów o niczym, sprawdzania, czy w telefonie nie pojawiła się nowa wiadomość, itp.,

${ }^{22}$ K. C. Berridge, T. E. Robinson, What Is the Role of Dopamine in Reward: Hedonic Impact, Reward Learning, or Incentive Salience?, „Brain Research Reviews” 28, 1998.

${ }^{23} \mathrm{~W}$ niniejszym tekście odwołuje się jedynie do fragmentu specyfiki działania dopaminy, która „wytwarzana przez neurony dopaminergiczne jest głównym neuroprzekaźnikiem katecholowym w mózgu ssaków. Pobudzając swoiste receptory, dopamina bierze udział w regulacji rożnych procesów, takich jak: utrzymanie postawy ciała i poruszanie się, zapamiętywanie, uczenie się oraz interpretowanie bodźców emocjonalnych”, J. Drożak, J. Bryła, Dopamina - nie tylko neuroprzekaźnik, „Postępy Higieny i Medycyny Doświadczalnej” 59, 2005, s. 405.

${ }^{24}$ To zresztą konieczny, wykształcony ewolucyjnie czynnik przetrwania. 
ponieważ Internet i telefon dają dzisiaj możliwość niemal natychmiastowej gratyfikacji podjętych poszukiwań. Co więcej, dopamina stymuluje ciagłość poszukiwań, nawet wówczas gdy uda nam się np. znaleźć jakaśs poszukiwaną w Internecie informację, i tak często nadal bezwiednie serfujemy - gdyż nasz mózg nastawiony jest bardziej na oczekiwanie nagrody (poszukiwania) niż samo jej zdobycie (stan satysfakcji) ${ }^{25}$. Dzisiaj nikogo już nie dziwi obraz dryfujacych na zatłoczonych ulicach wielkich miast setek ludzi trzymających w ręce telefony, stale utrzymujących kontakt z tym, co żyje w sieci. Ten i inne nałogi stają się ważnymi subświatami naszej codzienności i towarzyszą nam we wszystkich jej przestrzeniach.

Indywidualistycznymi nałogowymi konsumentami są też dzisiejsi małżonkowie/rodzice, a ich umiejętnie podsycane na co dzień pragnienia niekończących się poszukiwań nie sprzyjaja kształtowaniu spójnych i stabilnych (czyli pożądanych) przestrzeni życia rodzinnego. Te ostatnie zresztą nie oparły się marketingowym ingerencjom z zewnątrz, co jeszcze bardziej potęguje niezauważany stan rozregulowania. Ilustrują to często artykułowane przez samych zainteresowanych wyidealizowane obrazy własnych rodzinnych światów - dzisiaj, podobnie jak preferencje wyborcze, ulegające opiniotwórczej sile sondaży opinii publicznej, relacji publicystów, seriali telewizyjnych i reklam. Nawiązując do przytaczanych wcześniej wyników badań CBOS-u, odnoszę wrażenie ${ }^{26}$, że obecnie w Polsce przeważaja rodziny modelu mieszanego, chociaż często wydaje się ich członkom (szczególnie mężczyznom), że realizowany jest model partnerski. W tej specyficznej pozorności (lub płynnej rzeczywistości) małżeńsko/rodzinnego partnerstwa najważniejszą kwestia, dla interesujących nas realizacji wzorów socjalizacyjnych w rodzinnych przestrzeniach, jest nie tyle problem równego podziału obowiązków i przywilejów między małżonkami, ile nieumiejętne - w relacjach z własnymi dziećmi - dysponowanie mechanizmami kontroli, niekonsekwencje w podejmowanych decyzjach w sferze władzy oraz brak umiejętności osłabiania skłonności manipulacyjnych, które właśnie w modelu partnerskim i mieszanym zadomowiły się na dobre.

Konstruowanie partnerskich relacji pomiędzy małżonkami/rodzicami to zagadnienie bardzo często poruszane, zarówno w mediach, jak i w pracach naukowych. Zastanawiające jest natomiast to, że niemal całkowitym milczeniem otoczone są nieudolności procesu socjalizacji (poza drastycznymi przypadkami łamania prawa czy patologii), a to właśnie $\mathrm{w}$ tych przestrzeniach dochodzi współcześnie do najistotniejszych modyfikacji świata życia rodzinnego. Rodzice nie tworzą dziś silnego wspólnego socjalizacyjno-wychowawczego frontu, dają się podchodzić przez (coraz młodsze) dzieci uzyskujące nadmiar przywilejów (czyli sprawnie realizujące swoje wersje socjalizacji w rodzinie), zbyt ufają sile negocjacji, rezygnując z precyzyjnego wytyczania granic, osłabiają swoja (wynikająca z pozycji rodzica) władzę nad dziećmi, a jeszcze dodatkowo ulegając nastolatyzacji ${ }^{27}$ - zachowują coraz więcej cech młodzieżowych i nie tylko

${ }^{25}$ S. Weinschenk, Why We're All Addicted to Texts, Twitter and Google, 2012, www.psychologytoday.com (dostęp: 2.04.2014).

${ }^{26}$ Opierając się na własnych doświadczeniach badawczych.

${ }^{27}$ Nastolatyzacja to symboliczne podtrzymywanie przez dorosłych cech mile wspominanych z okresu młodości, ale przeniesionych do współczesności ich dorosłości. To podążanie za młodzie- 
przybliżają swój dorosły świat do świata dorastających dzieci, ale wcześniej zaczynaja traktować je w kategoriach partnerskich, tworząc relacje między dwoma równorzędnymi podmiotami interakcji.

Początek zasygnalizowanych powyżej zmian wytycza tak zwana epoka aktywnego rodzica, która zapoczatkowały nowego typu relacje rodzice-dzieci, jakie pojawiły się najpierw w Stanach Zjednoczonych, a później w Europie Zachodniej w drugiej połowie lat osiemdziesiatych XX w. W Polsce podobne tendencje zarysowały się $\mathrm{w}$ tym samym okresie. Rodzice ( $\mathrm{w}$ tym rozwiedzeni) zaczęli spędzać ze swoimi dziećmi więcej czasu niż ich poprzednicy w minionych latach, a dziecko zajęło centralną pozycję w rodzinie. Po części odpowiedzialna za tę modyfikację były ekspansja i niespotykana dotychczas popularność psychologicznych i pseudopsychologicznych teorii i poradników dla rodziców dostępnych na rynku księgarskim i czytelniczym (a od połowy lat dziewięćdziesiątych również w Internecie), które uruchomiły mechanizm niekończących się (nałogowych) poszukiwań nowych wartości w subświecie relacji z własnymi dziećmi. Lata dziewięćdziesiąte XX w. stały się „dekada dziecka", a od tamtej pory rodzice starali się i nadal starają jak najefektywniej angażować w codzienne życie swoich dzieci. Pomagaja przygotowywać plany (nie tylko edukacyjne) na przyszłość, uczestniczą (często jako widzowie, ale też jako doradcy) w podejmowanych przez nie działaniach sportowych, artystycznych, naukowych, a przede wszystkim wspieraja je symbolicznie przez stałe manifestowanie wiary w ich możliwości i szanse ich realizacji. Nie dotyczy to oczywiście wszystkich, ale w miarę możliwości rodzice starają się zagwarantować dzieciom i młodzieży maksimum komfortu psychicznego i umacniaja w nich silne przekonanie, że zawsze (a szczególnie wtedy, gdy coś im się nie powiedzie) mogą udać się do rodziców (rodzica) po wsparcie i pomoc ${ }^{28}$. Wydawać by się mogło, że nie ma w tym nic złego, ale to jednak tu właśnie zaczęły pojawiać się istotne niedoskonałości procesu pomyślnej socjalizacji, które skierowały ją w stronę niepomyślności. Znaczącym modyfikacjom w rodzinnych i pozarodzinnych przestrzeniach subświata wychowania uległy zarówno działania rodziców, jak i dzieci.

Pierwszą areną interesujących nas zmian stał się subświat szkoły. Od początku lat dziewięćdziesiątych XX w. stopniowo specyfika życia szkolnego ulegała przeobrażeniom, które na przełomie wieków wzmocniła jeszcze reforma

żowymi modami dla dorosłych i wykorzystywanie możliwości, na jakie pozwala dorosła niezależność, w maksymalizacji doznań w czasie wolnym i czasie zabawy oraz zaspokajanie potrzeb sztucznie tworzonych przez rynek dla dorosłych, którzy nie chcą do końca wydorośleć. Nastolatyzacja dorosłych to termin nawiązujący do infantylizacji Barbera, ale w moim odczuciu lepiej oddający sens interesujących nas cech współczesności. Myśląc o symbolicznej nastolatyzacji dorosłych, porównuję ich do starszych nastolatków, którzy przeważnie biologicznie są na tyle rozwinięci, że mogą konkurować z dorosłymi, natomiast proces osiagania przez nich dorosłości psychicznej jeszcze się nie zakończył. Potrafią zarówno beztrosko się bawić, jak i efektywnie pracować. Posiadaja już taki zasób wiedzy i kompetencji, że bez trudu odnajdują się w różnorodnych społecznych rzeczywistościach. Bywają jednak - podobnie jak dzieci-dorośli u Barbera - zwolennikami prostych, łatwych i szybkich rozwiązań i bywaja niecierpliwi. Szerzej zjawiskiem tym zajmuję się gdzie indziej (zob. W. Wrzesień, Europejscy Poszukiwacze, passim).

${ }^{28}$ Szerzej specyfikę epoki aktywnego rodzica omawiam gdzie indziej (zob. W. Wrzesień, Europejscy Poszukiwacze, passim). 
ustroju oświaty z 1999 r. Przekształceniom strukturalnym (m.in. zauważalnej obecności szkół niepublicznych ${ }^{29}$ ) towarzyszyło przedefiniowanie obecności rodziców w życiu szkoły. Większe ich zaangażowanie, wpisane ex definitione w charakter szkół społecznych z czasem zaczęło być coraz bardziej widoczne również w innych typach placówek szkolnych, w tym publicznych ${ }^{30}$.

$\mathrm{Z}$ tego powodu stopniowo dokonywała się redefinicja dotychczasowej specyfiki subświata szkoły. Aktywniej partycypujący w nim rodzice w większym stopniu, niż miało to miejsce wcześniej, zaczęli współtworzyć szkolną rzeczywistość. Mimo szeregu pozytywnych form działalności, w znacznej mierze łączącej się z funkcjonowaniem rad rodziców ${ }^{31}$ (w szczególności finansowego wspierania statutowej działalności szkoły), odnotować należy kilka cech negatywnych. Przede wszystkim rodzice, coraz konsekwentniej ingerując w programy wychowania (i nauczania niekiedy również), nieświadomie tworzyli podstawy do podważania statusu zawodowego nauczyciela oraz jego autorytetu wśród młodych, uczących się dopiero zasad funkcjonowania w dorosłym społeczeństwie. Zdarzało się nawet, że nauczyciele sami deklarowali, że boją się swoich uczniów ${ }^{32}$, a na współpracę z rodzicami mogą liczyć tylko w ograniczonym zakresie. Rodzice coraz częściej zaczęli stawać po stronie dzieci w sytuacjach ich niesubordynacji. Dotychczasowy system wychowania w szkole przestał działać. Uczniowie nie boją się potencjalnych kar, gdyż są one iluzoryczne lub można je obejść - przede wszystkim odpowiednio przedstawiając swoją wersję wydarzeń, co skutecznie mobilizuje rodziców do interwencji u dyrektora i załatwienia sprawy.

Wydaje się, że oddzielenie subświata rodzinnego od zewnętrznego świata szkoły z jej nienaruszalną i niekwestionowalną suwerennością (wykluczając oczywiście przypadki patologii), było sprawniejszym i bardziej bezpiecznym (dla całego społeczeństwa i jednostki) mechanizmem zarówno socjalizacji, jak i kontroli społecznej. Konieczność podporządkowania się normom instytucji (szkoły), bez możliwości odwołania się do (instytucjonalnej) pomocy ze świata rodzinnego, w znacznym stopniu ograniczała niepomyślne przebiegi ścieżek socjalizacji - indywidualistyczne wybory łączyły się z koniecznym podejmowaniem ryzyka i ponoszeniem potencjalnych kosztów ${ }^{33}$. Dzisiaj ryzyko niemal nie istnieje, a przekonanie o bezkarności sprzyja rozwijaniu niekorzystnych

\footnotetext{
${ }^{29}$ W 2013 r. w Polsce szkoły prowadzone przez organizacje społeczne i stowarzyszenia, organizacje wyznaniowe oraz pozostałe niepubliczne podmioty stanowiły następujący odsetek wszystkich szkół: 4,04\% szkół podstawowych; 4,98\% gimnazjów, 5,79\% liceów ogólnokształcących; 7,26\% szkół zawodowych i 2,72\% techników(GUS, Społeczeństwo informacyjne w Polsce w 2013 r., Warszawa 2013, s. 342).

${ }^{30}$ I w końcu znalazło swoje odzwierciedlenie w stosownych aktach prawnych (zob. przyp. 31).

${ }^{31} \mathrm{Na}$ mocy ustawy z 11 kwietnia 2007 r. o zmianie ustawy o systemie oświaty oraz o zmianie niektórych innych ustaw (Dz. U. 2007, Nr 80, poz. 542) obligatoryjnych w szkołach publicznych prowadzonych przez jednostki samorządu terytorialnego.

32 Przykładowe akty wandalizmu wobec mienia nauczycieli i ich zastraszania, zdiagnozowane w badaniach poznańskich liceów w 1997 r., omawiam gdzie indziej (zob. W. Wrzesień, Europejscy Poszukiwacze..., passim).

${ }^{33}$ Łamanie szkolnych norm zawsze stanowiło (i zapewne jeszcze długo będzie) atrakcję dla sporej grupy uczniów, jednak do niedawna aura zakazanego owocu łączyła się z realnymi obawami przed (niekiedy surowa) karą.
} 
(zarówno dla jednostki, jak i całego społeczeństwa) cech - samolubności, ignorancji, arogancji i irracjonalnego oporu w obronie własnych (słusznych i niesłusznych) racji.

Współczesnych rodziców charakteryzuje coraz silniej zauważalna niepomyślność socjalizacji do roli rodzica, co obserwujemy nie tylko w subświecie szkoły. Staja się rodzicami-indywidualistami, realizującymi zadania socjalizacyjne i dbającymi przede wszystkim o dobro własne (dobro mojego dziecka), a nie o dobro ogółu. W sytuacjach niesubordynacji w szkole, ale również w niemal wszystkich innych przypadkach przekraczania przez dzieci obowiązujacych norm ${ }^{34}$, rodzice bronia je, jakby bronili samych siebie. Przywoływanie dzieci do porządku odbieraja jak atak skierowany przeciwko nim samym. Nie odróżniaja przekazu treści socjalizacyjno-kontrolnych kierowanych wobec swoich dzieci (w założeniu przecież wspomagających ich socjalizację) od treści wrogich, adresowanych przeciwko rodzicom jako partnerom interakcji.

Niepomyślność socjalizacji do roli rodzica wpisuje się w szerszy kontekst współczesnego procesu infantylizacji dorosłych. Znaczna część dzisiejszych dorosłych ${ }^{35}$ nie w pełni wyrasta $\mathrm{z}$ dziecięco-młodzieżowej perspektywy ocen i definiowania sytuacji wraz z zachodzacymi w ich ramach interakcjami. Rodzice pełnią swoje role rodziców tak, jakby zapominali/nie wiedzieli (?), że socjalizacja jest procesem przystosowującym nowych młodych do życia w społeczeństwie dorosłych i właściwego (zarówno z perspektywy jednostki, jak i całego społeczeństwa) w nim funkcjonowania. Niepomyślna socjalizacja do roli rodzica w miejscu realizacji ogólnego dobra sytuuje indywidualistyczne interpre$\operatorname{tacje}^{36}$ („nikt nie będzie mi mówił, jak mam wychowywać swoje dziecko”). To z kolei nie skutkuje konstrukcją spójnych systemów norm, wartości i wzorów zachowań u socjalizowanych dzieci, lecz umiejętnością manipulacyjnego balansowania pomiędzy najkorzystniejszymi w danej chwili (z punktu widzenia dziecka) wariantami tożsamości i łączącymi się z nimi normami oraz wzorami zachowań. Niepomyślna socjalizacja rodziców do roli rodzica generuje niepomyślne przebiegi socjalizacji dzieci.

${ }^{34}$ Jeszcze stosunkowo niedawno zwrócenie uwagi rodzicom, że ich dziecko zachowuje się w sposób niewłaściwy (np. hałasuje, biega po restauracji, uderza w stoliki, przeszkadzając pragnącym w spokoju zjeść obiad gościom), skutkowało natychmiastowym przywołaniem go do porządku. Ewentualne negocjacje - stosowanie perswazji jako mechanizmu kontroli (najczęściej z dzieckiem, a nie z osobą zwracającą uwagę) - następowały później. Społeczny system kontroli w taki sposób kształtował system kontroli wewnętrznej rodzica, że zachowania dzieci (też starszych, w wieku młodzieżowym) niezgodne z obowiązującymi normami i wzorami zachowań wywoływały poczucie wstydu i poczucie niewłaściwie realizowanej roli społecznej matki/ojca oraz uruchamiały stosowne działania kontrolne wobec dzieci.

35 Uleganie infantylizacji i nastolatyzacji jest oczywiście względne i wskazanie precyzyjnych ram tychże jest zadaniem niezmiernie trudnym do realizacji. W powyższym zdaniu odnoszę się do dorosłych mniej więcej w wieku 20-55 lat (por. W. Wrzesień, Europejscy Poszukiwacze..., passim; B. R. Barber, op. cit.).

${ }^{36}$ Wzmacniane przez zbiór podpowiedzi, zinternalizowanych z przekazu poradniczego dla rodziców, w stylu: nie ograniczaj kreatywności swojego dziecka, pozwól swojemu dziecku rozwinąć pełnię jego możliwości, każde dziecko jest twórcze na tyle, na ile nie będziesz mu w tym przeszkadzał, samo dojdzie do tego, co jest dla niego najlepsze, pozwól rodzeństwu wynegocjować samemu wybór zabawy, nie ingeruj w świat dzieci zbyt nachalnie itp. 
Zmiany subświata szkoły pociagnęły za sobą modyfikacje subświata nauki i aktywności pozaszkolnych. Rodzice coraz bardziej przekonani (przekonywani), dzięki zachodzaccym w trakcie transformacji ustrojowej w Polsce przeobrażeniom (głównie natury ekonomicznej i społecznej), że współczesność narzuca konieczność zwiększenia inwestycji w dzieci tak, aby maksymalizować ich szanse na życiowy sukces, rozpoczęli tworzenie mniej lub bardziej rozbudowanych płaszczyzn wspierających edukację szkolna. Przeświadczenie o konieczności budowania jak najlepszego kapitału kulturowego dzieci, gwarantującego ich pomyślność w dorosłym życiu (przede wszystkim na rynku pracy), przełożyło się na częstsze wykorzystywanie dodatkowych form kształcenia i rozwoju umiejętności (nie tylko korepetycji). Szybko powstał rynek usług wspomagajacych szkołę, sprawnie dbający też o swoją marketingowo-reklamowa oprawę. Poza tym, jak często w takich przypadkach bywa, uruchomiony został silny mechanizm naśladownictwa i rywalizacji między rodzicami, którzy nierzadko na wyrost zaczęli organizować swoim dzieciom dodatkowe aktywności w ich przekonaniu wzmacniające symboliczny kapitał kulturowy i gwarantujące lepsze perspektywy na przyszłość. Warto w tym miejscu przywołać dane sondaży CBOS-u ${ }^{37}$ wskazujace wyraźną tendencję do finansowania przez znaczącą grupę rodziców ${ }^{38}$ aktywności pozaszkolnych swoich uczących się dzieci. W ostatnich latach zaobserwowano nieznaczną intensyfikację tej formy wspomagania konstruowania kapitału kulturowego, w ramach której na pierwszy plan wysuwają się nauka języków obcych i zajęcia sportowe, a na dalszych miejscach plasują się zajęcia artystyczne, korepetycje oraz kursy przygotowawcze $^{39}$. Wśród rodziców ponoszących takie koszty inwestycji w dzieci zdecydowanie przeważają osoby z wyższym wykształceniem, dobrze sytuowane i mieszkające w miastach powyżej pół miliona mieszkańców, co wiąże się nie tylko z większymi możliwościami, lecz także z wyższą świadomościa/przekonaniem o konieczności podejmowania powyższych kroków w celu zagwarantowania jak najlepszych podstaw startu w dorosłość. Nie bez znaczenia dla konstruowania korzystnego kapitału kulturowego, ale też i kapitału społecznego dzieci, pozostaje również wybór form i miejsc aktywności. Dobór elitarnych sportów (jeździectwo, tenis), odmian aktywności artystycznej (taniec, balet, gra na fortepianie) oraz bardziej prestiżowych miejsc (w których uczą się lub spędzają swój czas dzieci ze środowisk „właściwszych” dla doboru potencjalnych przyjaciół), staje się dla coraz większej grupy rodziców odpowiednim sposobem wspomagania przebiegu socjalizacji wtórnych swoich dzieci.

W pewnym stopniu zjawisko to wiąże się z nie zawsze w pełni uświadamianą przez rodziców realizacją własnych potrzeb, w szczególności potrzeby zachowania jak największej bliskości (emocjonalnej) z dzieckiem (i jego kontroli).

\footnotetext{
${ }^{37}$ Nawet mimo stosunkowo niewielkich liczebności prób badanych osób z dziećmi w wieku szkolnym, od największej - N=384 w roku 1998, do najmniejszej- N=217 w roku 2012 (CBOS, Wydatki rodziców na edukacje dzieci w roku szkolnym 2013/2014, Komunikat z badań, BS/151/2013, Warszawa 2013).

${ }^{38}$ Wyniki wahają się pomiędzy $29 \%(\mathrm{~N}=272)$ a $47 \%(\mathrm{~N}=217)$ (ibidem).

39 Odpowiednio w roku $2012(\mathrm{~N}=217)$ i 2013 (N=256): nauka języków obcych - 30\% i 28\%; zajęcia sportowe - 24\% i 27\%; zajęcia artystyczne - 16\% i 17\%; korepetycje i kursy przygotowawcze $-16 \%$ i $12 \%$.
} 
Dzisiaj współorganizacja (finansowanie) aktywności pozaszkolnych często łączy się z częściowym współuczestniczeniem, przede wszystkim w charakterze kierowcy (dzieci trzeba na zajęcia zawieźć), ale nierzadko również doradcy, pomocnika trenera czy widza (podczas zawodów, koncertów, przedstawień artystycznych, wystaw itp.). W tych symbolicznych przestrzeniach rodzice pojawiali się zawsze. Dzieciom (szczególnie w młodszym wieku szkolnym) z reguły zależało, aby rodzice znali ich osiagnięcia i byli z nich dumni. Dzisiaj różnica polega na tym, że dzięki wzorom przeniesionym na grunt europejski ze Stanów Zjednoczonych (i poradom zapoczątkowanym w epoce aktywnego rodzica) rodzice coraz częściej nie tylko pojawiają się w trakcie zajęć pozaszkolnych swoich dzieci, ale sytuują się (lub chcą być tak sytuowani) na pozycjach niegdyś zarezerwowanych dla rówieśników/przyjaciół i kolegów, co nie tylko osłabia ich pozycję jako rodzica w rodzinie, ale wprowadza też zaburzenia $\mathrm{w}$ przebiegu nabywanych kompetencji w procesach socjalizacji wtórnej. Niegdyś na przykład rywalizacja w klubie sportowym między innymi uczyła umiejętności wywalczenia sobie pozycji w grupie, odporności na przeciwności losu czy obrony swoich racji bez oglądania się na pomoc z zewnątrz. Dzisiaj rodzic/prywatny coach/przyjaciel stale obecny (chociaż niekoniecznie fizycznie) $\mathrm{w}$ przestrzeniach, w których w minionych latach dzieci zdane były jedynie na siebie, osłabia kształtowanie się cech, które na pewno mogą przydać się dzieciom zarówno w niedalekiej, jak i odleglejszej, dorosłej przyszłości.

Zasygnalizowane powyżej tendencje $\mathrm{w}$ widoczny sposób zredukowały też dotychczasowe przestrzenie subświata zabawy. Dzieci rzadko bawia się dziś na podwórkach. Nie tworzą zabawowych grup rówieśniczych z kolegami z sąsiedztwa, ponieważ często w ogóle ich nie znają. W czasach dominującej rejonizacji edukacji w najbliższej okolicy mieszkały całe roczniki chodzące do tej samej szkoły. Dzisiaj w dobie możliwości i wyboru jak najlepszych szkół (oraz tworzenia podmiejskich enklaw domów jednorodzinnych) koledzy ze szkoły, dowożeni przez rodziców niekiedy kilkadziesiąt kilometrów, nie spotykają się po lekcjach w swoim sąsiedztwie (gdyż przeważnie nie jest ono już ich przestrzenią wspólna), lecz są odwożeni bądź do domu, bądź w (zorganizowane) miejsca aktywności pozaszkolnych. Podwórko, tak ważna w minionych dekadach i w znacznym stopniu suwerenna od świata dorosłych przestrzeń socjalizacji wtórnej, w zasadzie przeszła do historii. Wyjątkiem są tu przydomowe place zabaw, ale tam (przeważnie małe) dzieci z reguły spędzają czas w towarzystwie rodziców/opiekunów.

Warto w tym miejscu odnotować, że do repertuaru wspólnych aktywności czasu wolnego-zabawy, od końca lat dziewięćdziesiątych XX w., wpisały się rytuały rodzinnego odwiedzania centrów handlowych (szczególnie w weekendy). Dzięki nim rodzice systematycznie (mimo że nieświadomie) wdrukowują dzieciom cechy nałogowych konsumentów, poszukujacych przyjemności w przestrzeniach sprzedaży. Starsze dzieci, już bez rodziców, chętnie bywają (nie tylko na zakupach) w kompleksach handlowych, które w ostatnich latach stały się ważnymi miejscami spędzania czasu wolnego-zabawy wśród młodzieży (oferując zreszta gamę wielu dodatkowych form rozrywki - kina, kluby fitness, bowling itp.). 
Redefinicji uległ również subświat wychowania w domu. W znacznym stopniu zyskał on swoje nowe oblicze dzięki popularyzacji nowych modeli wychowawczych stanowiących pokłosie epoki aktywnego rodzica. Dbałość o niezaburzanie suwerennego rozwoju osobowości dziecka, nierzadko połaczona $\mathrm{z}$ nieudolnością podejmowania ról ojca/matki ${ }^{40}$ (niepomyślna socjalizacja), doprowadziła do modyfikacji proporcji w dotychczas wykorzystywanych zbiorach mechanizmów kontroli społecznej. W ostatnich latach, ulegając po części marketingowym wpływom ekspansywnych poradników, rodzice zaczęli częściej stosować lepsze/bardziej adekwatne do naszych czasów (jak ich przekonano) miękkie mechanizmy kontroli. Indywidualistyczne, podparte nową wiedzą ${ }^{41}$, dystansujace się od dawnych metod $^{42}$ sposoby tworzenia nowych wewnątrzrodzinnych systemów kontroli wprowadziły w ich obrębie zupełnie nową jakość - centralną cechą stała się płynność i nieostrość granic obowiązujących reguł. Rodziców zaczęły charakteryzować nadmierna skłonność do negocjacji i brak umiejętności tworzenia wyraźnych pozycji społecznych, konstruujących przejrzysta, hierarchiczną strukturę kontroli w rodzinie. Przez dążenie do zapewnienia dzieciom maksimum komfortu psychicznego ${ }^{43}$ (następstwo treści promowanych przez branżę poradnictwa), zbyt wczesne sytuowanie dzieci na pozycjach quasi-partnerskich w stosunku do rodziców/dorosłych oraz brak konsekwencji w działaniach kontrolnych rodzice na własne życzenie osłabili swój wyższy, rodzicielski status w relacjach z własnymi dziećmi. W takiej nowej, płynnej rzeczywistości subświata wychowania nietrudno o wykorzystywanie nadarzających się okazji przez dzieci. Szybko się ucza, jak sterować (stosując dostępny im arsenał środków kontroli) przebiegiem działań tak, aby maksymalizować swoje korzyści. Młodsze dzieci potrafią umiejętnie unikać wszelkich czynności postrzeganych przez nich jako niedogodne (np. obowiązek sprzątania swojego pokoju, wnoszenia zabawek z ogrodu po skończonej zabawie ${ }^{44}$, wynoszenie śmieci itp.), starsze z biegiem lat stają się specjalistami od wyrafinowanych form manipulacji, sprawnie wykorzystując kontrolę pośrednia, opierajacca się na sile więzi emocjonalnych ${ }^{45}$. Dodatkowo, wraz z wzrostem wieku dzieci,

${ }^{40}$ Dobrym tego przykładem są wyniki ogólnoświatowego sondażu matek przeprowadzonego w 2013 r. przez agencję McCaan Truth Central: 61\% (N=6800) badanych chce mieć ze swoimi dziećmi relacje partnerskie, a za największą dla matki nagrodę uznaje nazwanie jej przez dziecko kumplem; 71\% (N=6800) matek nie widzi problemu w przyznaniu się przed dzieckiem do własnego błędu i za główną wartość uznaje autentyczność, a 73\% (N=6800) uważa, że we właściwym wychowaniu dzieci pomaga im ich własny instynkt. Zob. http://nowymarketing.pl/a/2546,koniec-ery-supermam-wyniki-badania-mccann-truth-central-cala-prawda-o-wspolczesnych-mamach?_ $\mathrm{r}=1$ ?_r=1 (dostęp: 3.04.2014).

${ }^{41}$ Czerpaną z poradników, czasopism i stron internetowych dla rodziców.

42 Jak nierzadko przekonują autorzy porad dla rodziców - niedobrych, nieodpowiednich, przestarzałych, niepasujących do naszych czasów.

${ }^{43} \mathrm{~W}$ tym niechęć do stosowania lub niekonsekwencje w stosowaniu kar.

${ }^{44}$ Gdy trzykrotne zwrócenie uwagi dziecku, aby wniosło rowerek do domu, kończy się wykonaniem tej czynności przez matkę, jej niekonsekwencja odbierana jest jako słabość i dziecko już wie, jak matką sterować w innych sytuacjach (w tym przypadku nabywa umiejętność wysługiwania się - jednego z typów manipulacji jako mechanizmu kontroli społecznej). To tylko jeden z wielu przykładów nieumiejętności realizacji roli kontrolera przez rodziców zaobserwowany w badaniach w $2013 \mathrm{r}$.

${ }^{45}$ Por. I. F. Nye, Family Relationships and Delinquent Behaviour, John Wiley, New York 1958. 
coraz wyraźniej w relacjach kontrolnych (wychowawczych) zaznaczają swoja obecność ekonomiczne środki kontroli. Rodzice chętnie korzystają z takich form motywacji, które w zasadzie są przekupywaniem dzieci, a te $\mathrm{z}$ wiekiem ucza się doskonale ten mechanizm wykorzystywać, w zasadzie kontrolując swoich rodziców, którym wydaje się, że to oni panują nad sytuacją ${ }^{46}$.

Równolegle z modyfikacją działań w rodzinnym subświecie wychowania przekształceniom ulegały scenariusze pełnienia ról rodzicielskich, wśród których szczególnie na uwagę zasługuja nowe zakresy realizacji roli ojca. Od kilkunastu lat obserwujemy większy udział ojców w czynnościach pielęgnacyjnych małych dzieci (w szczególności kapanie dzieci) oraz niemal rytualne wspólnie spędzanie czasu - na przykład spacery ojca z wózkiem (niegdyś obrazek niezmiernie rzadki w pejzażu polskich, i nie tylko polskich miast) czy pobyt na placach zabaw. Popularność wskazanych tu przykładowo form aktywności ojców stanowi efekt konsekwentnego wdrażania przez żony nowych wzorów z reguły zaczerpniętych z poradników lub czasopism oraz podpatrzonych w innych rodzinach ${ }^{47}$. To trochę takie modelowanie nowego ojca na siłę, które zresztą wpisuje się w szerszy kontekst współcześnie przebiegających przemian społecznych ról kobiet i mężczyzn.

Z jednej strony za sprawą modyfikacji uruchomionych w epoce aktywnego rodzica, z drugiej - na skutek działań ruchu feministycznego, a także dzięki stopniowemu wzrostowi popularności perspektywy gender studies, wypromowany został nowy model rodziny partnerskiej, w której „spotkać miałyby się raczej dwie Osoby niż mężczyzna i kobieta, a ich "przymierze» - sposób, w jaki rozegraja swoje bycie razem - zależeć miałoby bardziej od ich umiejętności komunikacji niż od jakichkolwiek predeterminowanych ról"48. Paradoksalnie, na co zwraca uwage cytowana Anna Giza-Poleszczuk, a potwierdzają to również wyniki moich badań, w większości ani kobiety, ani mężczyźni wcale dobrze się w takim nowym modelu partnerstwa nie odnajduja. I jedni, i drudzy trochę nie wiedza, jak podejmować i realizować nowe role w małżeństwie i rodzinie. Odnieść można wrażenie, że w pewnym stopniu brakuje precyzyjnie sformułowanych, wyraźnych oczekiwań związanych z rolami, zgody odnośnie do ich słuszności oraz potencjalnych ścieżek przebiegu takiego podejmowania ról, które nie budziłyby wątpliwości u osób starających się je realizować. W czasach płynnej rzeczywistości stan ten nikogo dziwić nie powinien, tymczasem nie ułatwia on konstruowania spójnej rzeczywistości życia rodzinnego. Możliwe, że między innymi z tego powodu część mężczyzn (świadomie lub nie

${ }^{46}$ Najpierw zabawki są np. nagrodą za dobre wyniki w nauce, później bez nagród dzieci nie chcą (lub udają, że nie chca) się uczyć, a przynajmniej potrafią tak przedstawiać swoje stany emocjonalne związane z nauką i nie tylko (stosując kolejne typy mechanizmu manipulacji, np. porównywanie - „bo w mojej klasie to już wszyscy mają nowe modele iPoda” lub wywoływanie poczucia winy „chyba nie chcecie, żebym straciła wszystkie koleżanki, bo wyglądam retro”), żeby rodzice mobilizowali je do pracy (kupując to, na czym aktualnie dziecku zależy) jeszcze przed osiąnięciem pożądanych rezultatów.

${ }^{47}$ Nie bez znaczenia pozostaje tu również przekaz medialny - seriale i programy, w których „lokowanym produktem” stają się promowane wzory życia małżeńskiego czy rodzinnego.

48 A. Giza-Poleszczuk, op. cit., s. 279. 
w pełni świadomie) poszukuje wsparcia w starych wzorach i stąd ich tradycjonalistyczne podejście do sposobów realizacji ról męża czy ojca ${ }^{49}$. Warto w tym miejscu jeszcze odnotować, że w rodzinach o cechach bardziej tradycyjnych wraz ze wzrostem wieku dzieci obserwujemy stopniowy wzrost socjalizacyjnej specjalizacji i intensyfikację działań przystosowujących do obowiązków typowych dla płci, generalnie jednak wypracowywanie obowiązkowości u dzieci jest słabą stroną socjalizacyjno-kontrolnej aktywności współczesnych rodziców.

Trochę wymuszoną nowymi stylami życia mobilność przestrzenną (rodzinną i pozarodzinna) wspomógł w ostatnich latach bardzo dynamiczny rozwój nowych technologii komunikacyjnych i towarzyszacych im nowych wzorów zachowań. Mniej więcej około 2000 r. koncerny telefonii komórkowej (właściwie na całym świecie, w tym i w Polsce) rozpoczęły w coraz bardziej intensywny sposób adresować swoje produkty/usługi do dzieci i młodzieży. Oczywiście płacić za nie musieli (i nadal musza) rodzice. Najpierw, wykorzystując istniejacy już w rodzinach od kilkunastu lat nowy klimat socjalizacyjno-wychowawczy, w którym nadopiekuńczość zyskała status niemal powszechnie obowiązującej normy, a wzmacnianie poczucia bezpieczeństwa rodziców stało się skuteczną formą oddziaływań marketingowo-reklamowych - wypromowano telefon komórkowy jako socjalizacyjnego asystenta rodzica. Rodzice uwierzyli, że telefon komórkowy dla dziecka to skuteczne narzędzie kontroli społecznej na odległość, podwyższające zarówno jego bezpieczeństwo, jak i komfort psychiczny rodziców. W niedługim czasie okazało się, że telefon komórkowy do tego stopnia przyją się w świecie dzieci i młodzieży (został w pełni zaakceptowany przez rodziców), że koncerny telefonii komórkowej nie musiały odwoływać się do wyższych celów, a mogły skupić się na sprzedaży zabawy i rozrywki. Szczególnie po utworzeniu wspólnej telefoniczno-internetowej przestrzeni równoległej dzieci i młodzież stali się jednymi z głównych beneficjentów nowych technologii, znacząco modyfikujących ich styl życia.

Nowoczesne technologie komunikacyjne i dobrodziejstwa nowych możliwości, które oferują na co dzień, mają niestety wyraźne skutki uboczne, zmieniając rzeczywistości życia codziennego, w tym w rodzinie. W charakterystyczny sposób stają się na przykład czynnikami reorganizacji rodzinnych przestrzeni wspólnych. Jeszcze stosunkowo niedawno do takich przestrzeni (oprócz np. wspólnie spędzanych świąt i uroczystości rodzinnych, wyjazdów wakacyjnych, niekiedy wspólnych posiłków) zaliczało się wspólne uczestnictwo w kulturze medialnej - głównie realizowane poprzez rodzinne oglądanie telewizji, ale też filmów video i DVD, a czasami słuchanie muzyki. Współcześnie (przy stale rosnaccym odsetku gospodarstw domowych w Polsce posiadajacych komputer i dostęp do Internetu; $\left.{ }^{50}\right)$, coraz częściej dzieci i rodzice, mając swoje własne komputery, spędzają więcej czasu sami, przed własnymi monitorami, a wspól-

${ }^{49}$ We wszystkich typach rodzin (nie tylko w rodzinach modelu tradycyjnego) pojawia się podział obowiązków, nawiązujący do stereotypowego postrzegania różnic płci i takiego też wdrukowywania oczekiwań związanych z rolami żeńskimi i męskimi, np. chłopcy w domu nie sprzątają (nawet własnego pokoju), ponieważ ojciec też w mieszkaniu w ogóle nie sprząta, a matka zachowuje się jak służąca i jeszcze sprawia wrażenie, że ją to cieszy. Por. D. Duch-Krzystoszek, Kto rzadzi $w$ rodzinie. Socjologiczna analiza relacji $w$ matżenstwie, Wyd. IFiS PAN, Warszawa 2007.

${ }^{50}$ Por. GUS, Społeczeństwo informacyjne w Polsce w 2013 r., Warszawa 2013. 
ne uczestnictwo w kulturze medialnej traci swoje dotychczasowe pozycje $\mathrm{w}$ rodzinnych formach aktywności. Poza tym coraz silniej widoczne jest swoiste zawłaszczanie przestrzeni domu rodzinnego przez równoległe subświaty telefoniczno-internetowe. Przede wszystkim dzieci (ale niekiedy i rodzice) w efekcie utrzymywania ciagłego (skutecznie działa pętla dopaminowa) kontaktu $\mathrm{z}$ rówieśnikami ${ }^{51} \mathrm{w}$ sieci (permanentnego kontrolowania przebiegu wydarzeń na telefonach, tabletach, laptopach) sa obecne i jednocześnie nieobecne w świecie życia rodzinnego. Tworza przestrzenie graniczne, a ich liminalność o wiele bardziej służy funkcjonalności subświata sieci niż rodziny. Graniczna obecność-nieobecność wkracza w świat życia rodzinnego, częściowo (a niekiedy niemal całkowicie) eliminując jego uczestników z systemu interakcji i przebiegów działań w świecie rzeczywistym, które stanowią podstawy tworzenia spójnych rodzinnych przestrzeni ${ }^{52}$.

Na wszystkie omówione powyżej kierunki modyfikacji subświatów życia rodzinnego nakłada się zbiór tendencji globalnych, stanowiących następstwo dominacji kultury konsumpcyjnego kapitalizmu, dla której najbardziej pożądanymi bohaterami są nałogowi konsumenci. Odwołując się do naszych biologicznie warunkowanych skłonności do uzależnień, konsumpcyjny kapitalizm nie tylko tworzy sztuczne potrzeby, lecz również ekspansywnie zawłaszcza sfery potrzeb pierwotnych, naturalnych. Umiejętnie wprowadza w te sfery nowe formy marketingu ${ }^{53}$, w efekcie których współczesnym ludziom dostarczane są nowe narzędzia (czyli: lepsze, atrakcyjniejsze, takie, które wszyscy chca mieć itp.), wykorzystywane w działaniach znanych od dawna i realizowanych jak dotąd bez większych przeszkód. Teraz okazuje się, że na przykład bez poradników, kursów, blogów, grup wsparcia itd. nie uda się dobrze wychować własnych dzieci ${ }^{54}$. Jednocześnie wzmacnia się potrzebę troskliwości i dbania o jak najwięcej aspektów socjalizacji dziecka. Przecież we wszystkich tych przestrzeniach można sprzedawać kolejne produkty, które również moga uzależniać - zabawki dla dzieci, gadżety, formy spędzania czasu, o nowych telefonach i aplikacjach na nie nawet nie wspominajac $c^{55}$.

Konsumpcyjny kapitalizm, posługując się nowymi metodami marketingu ${ }^{56}$, stara się uzależnić ludzi od przedmiotów i usług, wmawiając im, że wykorzy-

${ }^{51}$ To oczywiście nie dotyczy rodziców, ale wcale nie oznacza, że nie włączają się w aktywności internetowych wspólnot (na forach specjalistycznych czy popularnych społecznościowych - NK, Facebook, Tweeter), a także potrafią namiętnie śledzić np. notowania giełdowe, aukcje, wydarzenia sportowe itp.

${ }^{52}$ Współcześnie sygnalizowane tu zjawisko obecne jest w zasadzie we wszystkich przestrzeniach naszej codzienności, w których istnieje dostęp do (mobilnego) Internetu, i w podobny sposób upośledza przebieg działań i interakcji.

53 Wzmacniającego nasze uzależnienie od towarów i usług.

54 Zob. kuriozalne przykłady zaczerpnięte z branży poradnictwa wychowawczego omawiane przez Gizę-Poleszczuk (op. cit., s. 274-282).

$55 \mathrm{Na}$ uzależnienie matek od smartfonów i Internetu zwracał uwagę sondaż McCann Worldgroup z maja 2013 r. (zob. http://tech.wp.pl/kat,1009781,title,Wspolczesna-matka-uzalezniona-od-smartfona,wid,15686167,wiadomosc.html?ticaid=110aaa; dostęp 14.03.2014).

${ }_{56} \mathrm{~W}$ tym silnie manipulacyjne: np. neuromarketing, marketing partyzancki, lokowanie produktu, marketing wirusowy, cool hunting, reality advertising itp. Zob. m.in. G. Zaltman, Jak myśla klienci. Podróż w głab umysłu rynku, Forum, Poznań 2004; J. Zwieg, Your Money and Your 
stując je, tworzą nowe, lepsze przestrzenie swojego życia, w tym rodzinnego. Zmanipulowanym uzależnionym wydaje się, że wszystko, co robia, jest dobre i funkcjonalne dla ich dzieci, dla nich samych, dla rodziny ${ }^{57}$, a nie zauważaja, że są przede wszystkim źródłem stałego zysku. Im wystarcza to, że dobrze się czuja, przede wszystkim bezpiecznie. Obserwują też innych robiacych to samo i utwierdzają się w stosowności własnych działań. Jak to możliwe, żeby tak wielu miało się mylić? Naśladownictwo staje się efektywnym mechanizmem marketingu pośredniego, chociaż przeczy tak chętnie promowanej ideologii indywidualizmu. Paradoksem naszych czasów - czasów propagandy indywidualizmu - jest fakt, że najwięcej zarabia się na umiejętnie kamuflowanym tłumieniu indywidualizmu. W zasadzie żyjemy w świecie zuniformizowanym, w którym dominuje niedostrzegana uniformizacja (indywidualistów), będąca wyraźnym przejawem uzależnień od przedmiotów, usług, stylów, mód itd. Wszyscy chcą mieć to samo życie i te same produkty. Nikt nie zastanawia się już, czy potrzebny jest mu telefon komórkowy lub tablet, lecz po prostu chce go mieć (natychmiast) - taki sam, jak maja inni. Współcześni indywidualistyczni nałogowi konsumenci nie są w żadnej mierze indywidualistami, chociaż im się to wmawia.

Infantylizacja i nastolatyzacja, wraz z uzależnieniem od produktów i usług oferowanych na rynku, modyfikuje wzajemne relacje w rodzinie i tworzy nowe jakości istniejących tam przestrzeni (subświatów). Pojawiające się coraz to nowe przedmioty, technologie i usługi zmieniają świat życia rodzinnego w sposób prawie niezauważalny. Na skutek bardzo sprawnie zaplanowanych i przeprowadzanych działań marketingowych rodzice oraz ich dzieci zdają się zauważać jedynie pozytywne strony dokonujących się zmian. Nikt nie dostrzega zdalnego sterowania przez świat biznesu, dla którego negatywne efekty uboczne własnych kampanii marketingowych są tylko wtedy ważne, gdy zakłócaja maksymalizację zysku ${ }^{58}$. A to między innymi właśnie one - skutki uboczne uzależniających kampanii marketingowych modyfikują dzisiejsze życie rodzinne i są odpowiedzialne za pojawianie się w jego ramach nowych wartości, norm i wzorów zachowań.

Współczesność charakteryzuje ciagłe poszukiwanie nowych satysfakcjonujących doznań. Inni wokół nas szukaja, koncerny podrzucają nowości, a my podążamy wytyczonym szlakiem, coraz bardziej uzależniając się od samych poszukiwań. Poszukiwania nowych produktów, usług, stylów, mód modyfikuja też wzajemne relacje między małżonkami oraz rodzicami i dziećmi. Wszyscy

\footnotetext{
Brain. How The New Science of Neuroeconomics Can Make You Rich, Simon \& Schuster, New York 2007; K. Zięba, Granice etycznych praktyk marketingowych w zakresie nowych form promocji, w: L. Garbarski (red.), Kontrowersje wokót marketingu w Polsce - tożsamość, etyka, przyszłość, Wyd. WSPiZ im. Leona Koźmińskiego w Warszawie, Warszawa 2004; J. Wiktor, Reklama - między perswazja a manipulacja. Etyczne kontrowersje wokót komunikacji marketingowej, w: L. Garbarski (red.), op. cit.

${ }^{57}$ Podwyższa się poczucie komfortu psychicznego, redukowane są lęki, zaspokajana jest potrzeba bezpieczeństwa itp.

${ }^{58}$ Nikogo z producentów preparatów odchudzających nie interesuje, że promocja szczupłej sylwetki może zaburzać proces rozwojowy i szkodzić nastolatkom. Podobnych dylematów nie maja producenci niezdrowej żywności, gier komputerowych, telefonów komórkowych itd.
} 
(na skutek siły uzależniających oddziaływań marketingowych oraz niecierpliwości i chciwości - cech infantylizacji i nastolatyzacji) dynamizujemy codzienność ciagłym podążaniem za informacja, stałą komunikacją z grupami bliskich i znajomych, bezustannym poszukiwaniem innowacji, nowych towarów, usług i przyjemności. Życie współczesnego człowieka nie może dziś być nudne, a skoro tempo wprowadzania nowości jest tak duże i cały czas przekonuje się nas, że wiąże się z tym możliwość nieograniczonego wyboru i indywidualnego tworzenia własnych światów, miast, samego siebie, to $\mathrm{z}$ upodobaniem z tego korzystamy, nie zauważając własnego rzeczywistego miejsca w tym procesie. Konsumpcyjny kapitalizm, nieustannie wykorzystując osobliwości myślenia ludzi i podążania podpowiadanymi kierunkami, maksymalizuje swoje zyski. Dzięki naszemu emocjonalnemu myśleniu sprzedaje nam się produkty, przekazuje informacje, zachęca do zmian stylu życia. Te bardzo silne, manipulacyjne działania nie pozostają bez wpływu na świat życia rodzinnego, zmieniając dotychczasowe scenariusze realizacji rodzinnych ról i specyfikę codziennych wzajemnych relacji w przestrzeniach rodzinnych subświatów - teraz zasiedlanych przez nałogowych konsumentów. W najbliższych latach warto będzie się im uważnie przyglądać.

dr hab. Witold Wrzesień

Profesor Uniwersytetu im. Adama Mickiewicza w Poznaniu

witoldww@gmail.com

\section{MODIFICATIONS OF FAMILY PATTERNS OF SOCIALISATION IN COMPULSORY CONSUMERIST SOCIETY}

\section{Summary}

The recent civilisation and culture changes have modified the family life in Polish families. The contemporary infantilised consumerist capitalism enhances ambiguity and flexibility of norms and patterns of behaviour in everyday life. Thus, a sale-based consumerist capitalism develops and promotes a new type of hero - a compulsive consumer. This is, among others, the reason why new features of socialisation processes such as patterns of unsuccessful socialisation not only occur but seem to be desired. The ineptly implemented models of family life of earlier socialisation processes cause turmoil in the upbringing processes and children, instead of learning how to respect the rules, learn how to circumvent them. Children manipulate and effectively drift between different versions of the same or different worlds of everyday life - they play with their still forming identity. This ability, in turn, becomes crucial for modern secondary socialisation, which in order to enhance the features of compulsive consumer requires smooth shifting between different identities. The article is an attempt to diagnose the changes that have recently, in a rather insensible manner, brought in significant new qualities in the fundamental space of our life - the family. 
Copyright of Journal of Law, Economics and Sociology is the property of Faculty of Law and Administration of Adam Mickiewicz University in Poznan and its content may not be copied or emailed to multiple sites or posted to a listserv without the copyright holder's express written permission. However, users may print, download, or email articles for individual use.

Właścicielem praw autorskich do „Ruchu Prawniczego, Ekonomicznego i Socjologicznego” jest Wydział Prawa i Administracji Uniwersytetu im. Adama Mickiewicza w Poznaniu. Zawartość czasopisma nie może być kopiowana, przesyłana do innych stron internetowych bądź zamieszczana na blogach bez pisemnej zgody wydawcy. Niemniej artykuły można drukować, kopiować lub przesyłać w formie elektronicznej na własny użytek. 